\title{
Jurassic-Cretaceous lacustrine deposits in the East Gobi Basin, southeast Mongolia
}

Hisao Ando ${ }^{1}$, Hitoshi Hasegawa ${ }^{2}$, Takashi Hasegawa ${ }^{3}$, Toru Ohta ${ }^{4}$, Masanobu Yamamoto ${ }^{5}$, Noriko Hasebe ${ }^{6}$, Gang $\mathrm{Li}^{7}$ and Niiden Ichinnorov

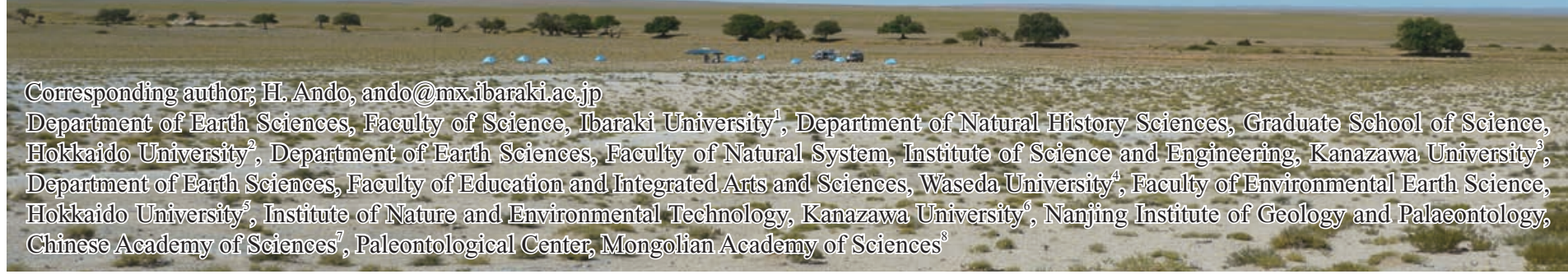

Received June 29, 2011 Accepted September 16, 2011

The Jurassic-Cretaceous period is characterized by extremely warm "greenhouse" climate, elevated atmospheric $\mathrm{CO}_{2}$ levels, and repeated occurrences of Ocean Anoxic Events (OAEs); however, detailed processes and causal mechanisms of these marked events, particularly the response of terrestrial climate system, have been poorly understood. To evaluate the interaction between the land and the ocean during OAE interval, we investigated terrestrial paleoenvironments at intra-continental sites in eastern Eurasia.

The East Gobi Basin of southeast Mongolia contains widespread lacustrine deposits of the mid-Cretaceous and the Early-Middle Jurassic age (Jerzykiewicz and Russell, 1991). In order to reconstruct terrestrial paleoenvironmental changes during the intervals of OAEs, we examined the mid-Cretaceous (Shinekhudag Formation) and the Middle Jurassic lacustrine deposits (Eedemt Formation) in southeast Mongolia.

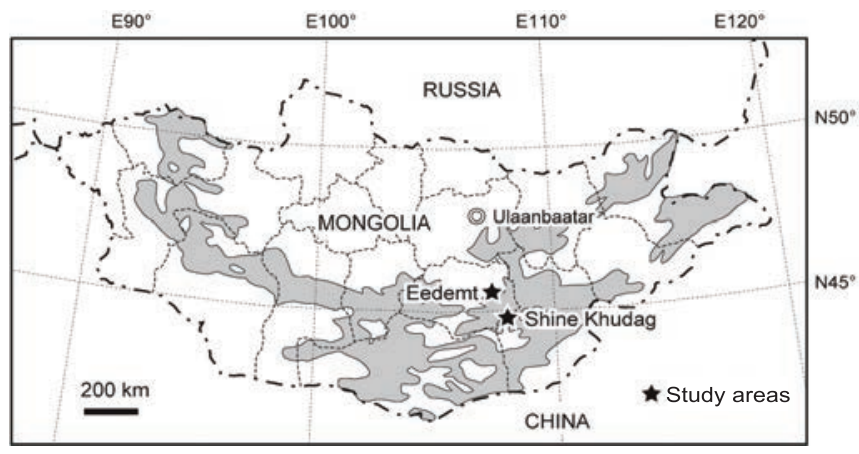

Fig. 1. Map showing the distribution of Jurassic-Cretaceous sedimentary basins in Mongolia and the locations of study areas.

\section{(1) Shine Khudag Area (Aptian)}

The Shinekhudag Formation, well exposed in the Shine Khudag area in the Shaazangiin Gobi region, is composed of dark grey paper shale, grey calcareous shale, and whitish, yellowish to brownish dolomite (Fig. 2). The strata are continuously exposed up to $400 \mathrm{~m}$ in thickness. The shale and dolomite successions are rhythmically alternated (decimeter-, meter-, and tens of meter-scale), which can be controlled by orbital cycles. The paper shale and calcareous shale include micrometer-scale laminations, which are most likely of varve origin (Fig. 3).

The age of the Shinekhudag Formation is assigned as Aptian or Barremian-Aptian based on the conchostracans, ostracods, floral and molluscan fossil evidence (Jerzykiewicz and Russell, 1991), and $\mathrm{Ar}^{40} / \mathrm{Ar}^{39}$ dating of basaltic rocks in the uppermost part of the underlying Tsagantsav Formation (ca. 121-125 Ma: Graham et al., 2001).
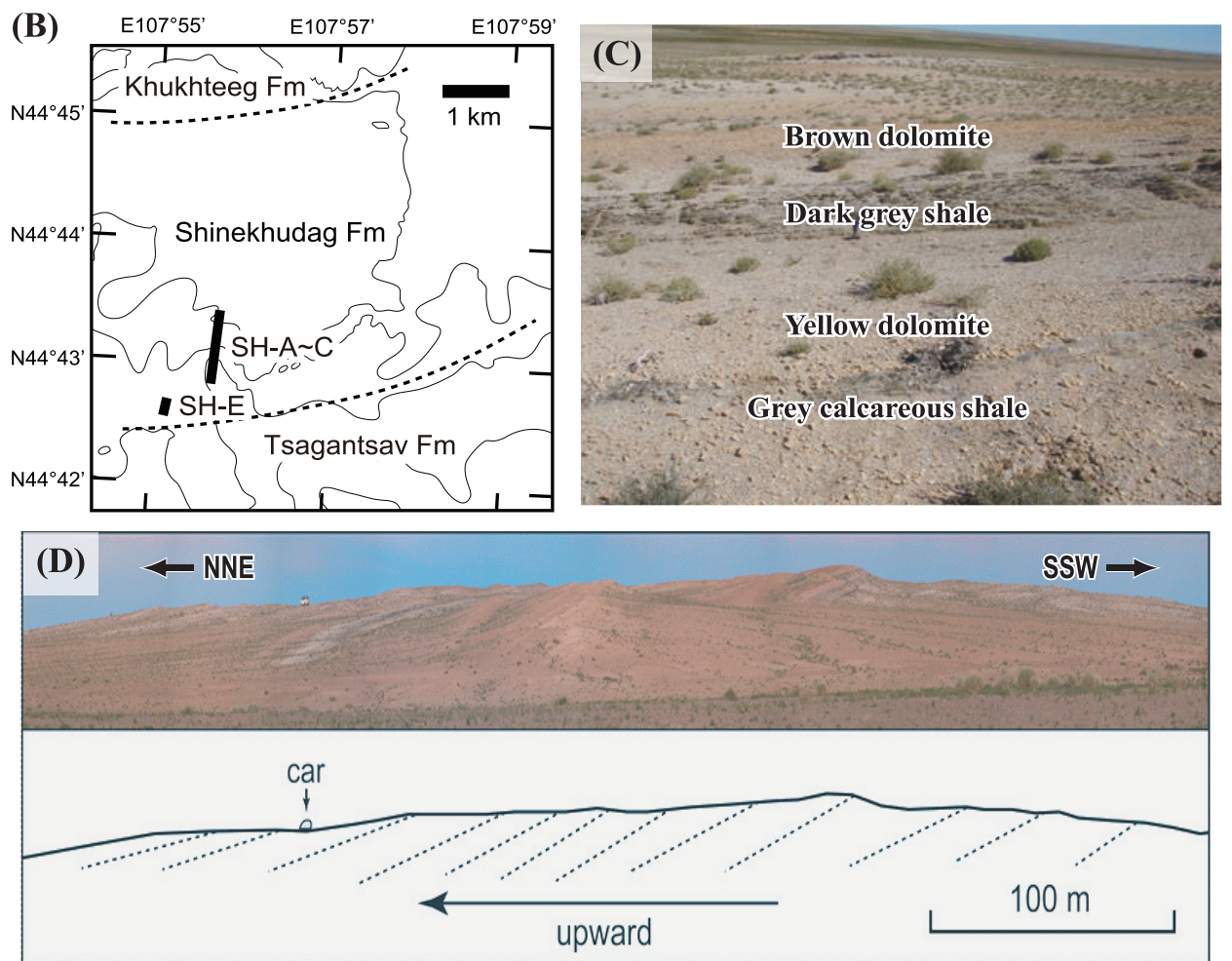

(A)

\begin{tabular}{|c|c|c|c|}
\hline Age & Formation & Lithology & $\begin{array}{l}\text { Thick- } \\
\text { ness }\end{array}$ \\
\hline$\frac{\frac{c}{0}}{\frac{0}{2}}$ & $\begin{array}{l}\text { Khukhteeg } \\
\text { Formation }\end{array}$ & & $100 \mathrm{~m}$ \\
\hline$\frac{\frac{c}{0}}{\frac{0}{\frac{0}{2}}}$ & $\begin{array}{c}\text { Shinekhudag } \\
\text { Formation }\end{array}$ & 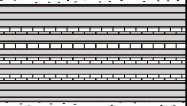 & $450 \mathrm{~m}$ \\
\hline $\begin{array}{l}\frac{1}{\pi} \\
\oplus \\
\frac{1}{0} \\
\infty\end{array}$ & $\begin{array}{c}\text { Tsagantsav } \\
\text { Formation }\end{array}$ & 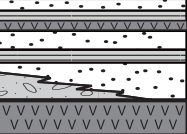 & $>500 \mathrm{~m}$ \\
\hline
\end{tabular}

(E)
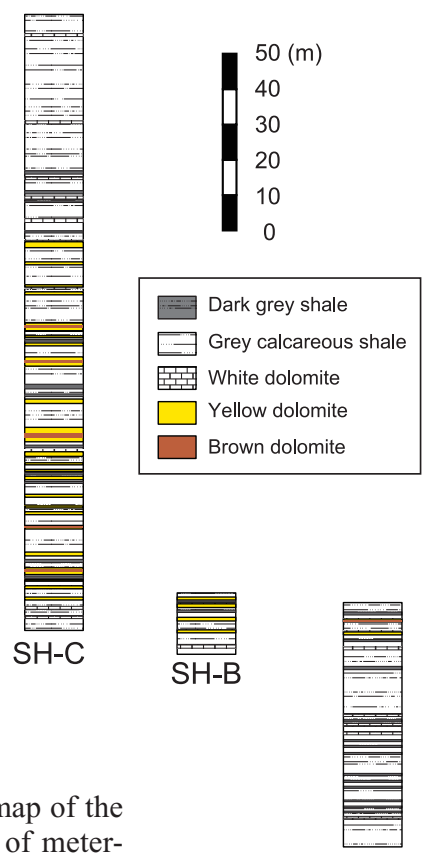

$\mathrm{SH}-\mathrm{A}$

Fig. 2. (A) General stratigraphy of the Lower Cretaceous formations in the East Gobi basin, (B) location map of the
Shinekhudag, and the overlying Khukhteeg and underlying Tsagantsav formations, (C) field photograph of meterscale alternating beds of shale and dolomite, (D) photograph of Shine Khudag hill, and (E) lithologic columns of the middle part of Aptian lacustrine deposits (Shinekhudag Formation) in the Shine Khudag area. 

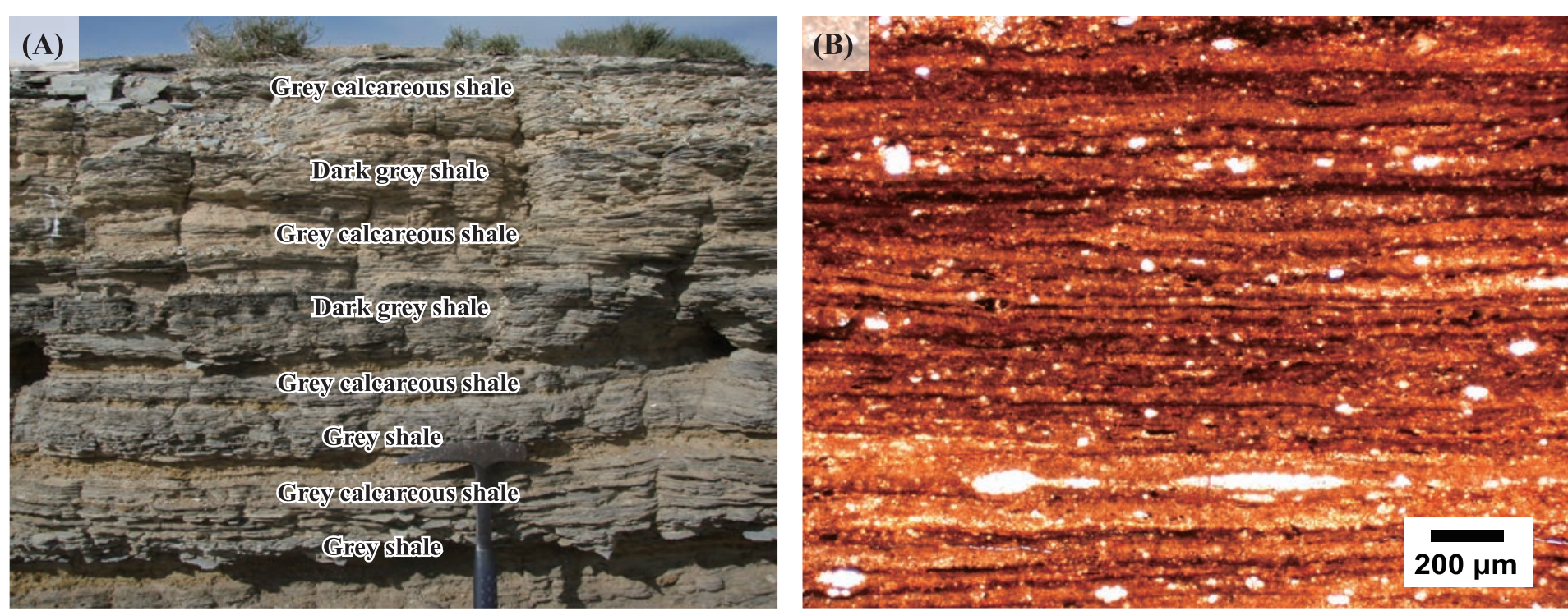

Fig. 3. (A) Outcrop photograph of alternating beds of dark grey shale and grey calcareous shale in the Shinekhudag Formation. (B) Microphotograph of a shale layer showing micrometer-scale laminations that probably represent varves.

\section{(2) Eedemt Area (Middle Jurassic)}

The Eedemt Formation, well exposed in the Eedemt area in the Khootiin Khotgor region, is composed of dark grey paper shale (oil shale), grey calcareous shale, silty mudstone, sandstone and conglomerate (Fig. 4). The age of the strata is newly defined as Middle Jurassic, based on the conchostracans biostratigraphy (Fig. 5). These shale and silty mudstone successions are also rhythmically alternated (decimeter-, meter-, tens of meter-scale).

(A)

\begin{tabular}{|c|c|c|c|}
\hline Age & Formation & Lithology & $\begin{array}{l}\text { Thick- } \\
\text { ness }\end{array}$ \\
\hline 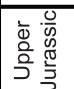 & $\begin{array}{l}\text { Kerulen } \\
\text { Formation }\end{array}$ & 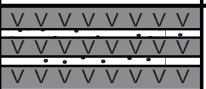 & $80 \mathrm{~m}$ \\
\hline 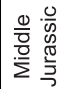 & $\begin{array}{l}\text { Eedemt } \\
\text { Formation }\end{array}$ & & $150 \mathrm{~m}$ \\
\hline 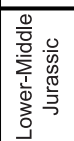 & $\begin{array}{c}\text { Khootiin } \\
\text { Khotgor } \\
\text { Formation }\end{array}$ & (1) & $200 \mathrm{~m}$ \\
\hline
\end{tabular}

○ conglomerate $\square$ sandstone $⿴$ shale $\square$ coal $\square$ basalt
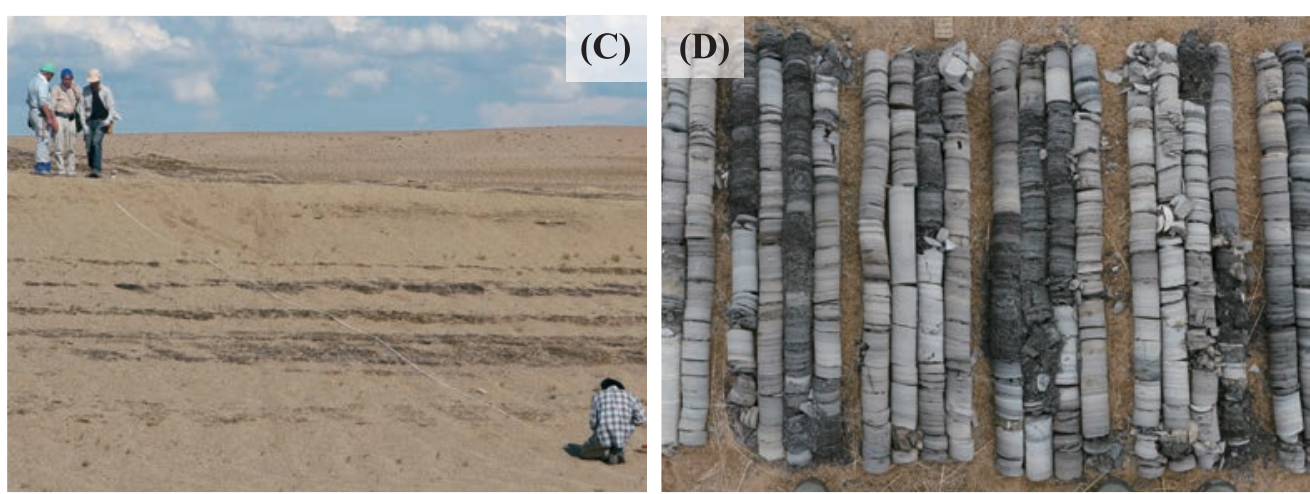

(B)

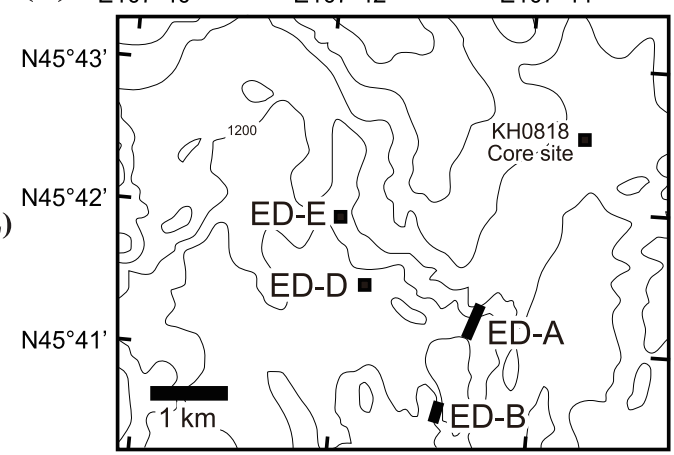

Fig. 4. (A) General stratigraphy of the Jurassic formations in the Khootiin Khotgor region, (B) location map of the Eedemt area and the study sections, (C) outcrop photograph, (D) drilled cores, and (E) lithologic columns of Middle Jurassic lacustrine deposits (Eedemt Formation).
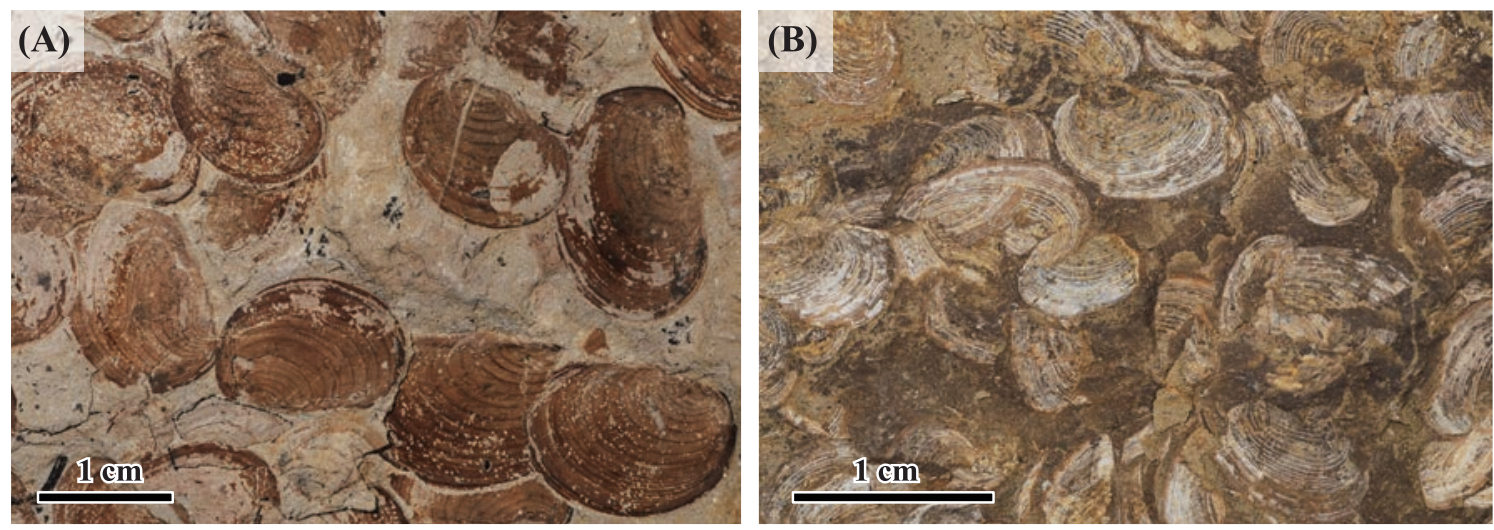

Fig. 5. Conchostracans on bedding surfaces in the Shinekhudag Formation (A) and in the Eedemt Formation (B). XII
(E)

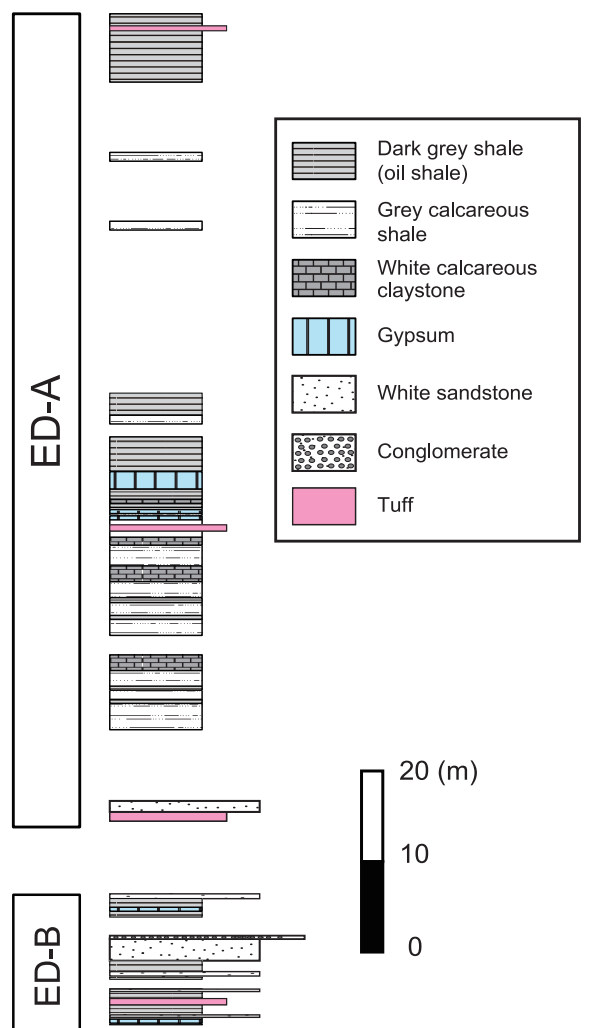

\section{References}

Graham, S. A., et al., 2001, Sedimentary record and tectonic implications of Mesozoic rifting in southeast Mongolia. Geol. Soc. Amer. Bull., 113, 1560 1579.

Jerzykiewicz, T. and Russell, D. A., 1991, Late Mesozoic stratigraphy and vertebrates of the Gobi Basin. Cret. Res., 12, 345-377. 